\title{
TRADICIÓN, VANGUARDIA Y POÉTICA EN MADRIGAL AL BILLETE DE TRANVÍA DE RAFAEL ALBERTI
}

RAQUEL MACCIUCI

Universidad Nacional de La Plata

\section{RESUMEN}

El diálogo que la vanguardia española entabló con la tradición - fenómeno común también a Latinoamérica - ha dado lugar a interpretaciones parceladas del arte y de la literatura del temprano siglo xx, y muy especialmente, de la poesía de la llamada Generación del 27. En las últimas dos décadas, las aproximaciones de la crítica han demostrado que la alianza entre el pasado y lo nuevo está lejos de constituir una rémora que condena a los ismos hispánicos a arrastrar un estigma de inautenticidad, acusados de carecer del impulso transformador de los programas artísticos de los países europeos tempranamente modernizados. A partir de las recientes tesis que han revisado estas premisas (Soria Olmedo, Geist, Bosi, García Montero, Wilson...), se analizará el muy citado poema «Madrigal al billete de tranvía» de Rafael Alberti con el fin de explorar, en un texto de creación específico, la puesta en práctica de una estética que reelaboró en clave vanguardista los patrones líricos heredados. Asimismo, se verá que, tras el hermetismo del discurso neogongorino del madrigal, subyace el manifiesto breve de una poética cuyo desciframiento enriquece la lectura de la obra albertiana de los años veinte.

Palabras clave: Vanguardia, tradición, Rafael Alberti, Cal y canto, poética.

\section{TRADITION, AVANT-GARDE AND POETICS IN «MADRIGAL AL BILLETE DE TRANVÍA» BY RAFAEL ALBERTI}

\section{ABSTRACT}

The dialogical relation that the Spanish Vanguard settled with tradition - a usual phenomenon also in Latinamerica - has given place to parceled interpretations of the art and literature of the early xxth century, and, specially, of the poetry of the so-called "Generación del 27». During the last two decades, critical approaches has shown that the alliance between the past and «the new» is far from being an obstacle that condemns the Spanish «ismos» to be seen as inauthentic ones, and therefore to be accused of not having the transformative impulse that characterized the artistic projects of the early modernized European countries. Based on the recent works that have reviewed these premises (Soria, Olmedo, Geist, Bosi, García Montero, Wilson...), the purpose of this article is to analyze the well known (and many times cited) Rafael Alberti's poem «Madrigal al billete de tranvía», with the aim to explore, in a creative text, the manifestations of a vanguardist aesthetic that re-elaborated the lyric models inherited from the tradition. In addition to this, this article aims to show that, below the hermeticism of the «neo-Gongorian» madrigal discourse, lies the brief manifesto 
of a poetics whose decipherment enriches the interpretations of Alberti's works during the $20 \mathrm{~s}$.

Key words: Vanguard, Tradition, Rafael Alberti, Cal y canto, Poetics.

Un libro es como un jardín que se lleva en el bolsillo. Proverbio árabe

Un libro, como un viaje, se comienza con inquietud y se termina con melancolía.

José Vasconcelos

\section{LA LIBRE DISPONIBILIDAD DE LOS CLÁSICOS ${ }^{1}$}

Generación del 27 seguirá siendo una noción válida para identificar a un grupo de poetas españoles de proyección universal; no es plausible imaginar otro nombre que no requiera un sinfín de excursos para especificar la referencia. Sin embargo, es sabido que tal nominación, además de haber instaurado un numerus clausus un tanto injusto, construyó un campo de la poesía española segregado del fundamental movimiento estético de las vanguardias europeas y del rumbo de las artes en el propio suelo y en el mundo hispanoamericano ${ }^{2}$.

Posteriormente, cuando los poetas del 27 son integrados por la crítica en el legítimo marco de las vanguardias históricas, surgirá la controversia acerca de cómo entender el diálogo de estos con la tradición, bien se trate de la poesía popular, del cancionero, o de los nombres más representativos de los Siglos de Oro. La idea de que la vanguardia española fue bipolar porque en gran medida continuó aferrada a las letras del pasado prevaleció en estudios señeros como el de José Luis Tejada, en cuyo título dicha evaluación es bien notoria: Rafael Alberti entre la tradición y la vanguardia (1977). Parece percibirse en dichas aproximaciones una suerte de naturalización del fenómeno a la hora de explicar que la fuerza modernizadora en España no fue tan arrolladora como para adoptar un radical rechazo del pasado, como propugnaron otros ismos europeos.

Desde distinta zona de la crítica —en la que se encuentra, entre otros, Eduardo Subirats- se intenta comprender más a fondo el aparente oxi-

${ }^{1}$ El presente trabajo profundiza y amplía conceptos vertidos en la ponencia «"Madrigal a un billete de tranvía' de Rafael Alberti. (Para seguir revisando el tópico 'tradición más vanguardia')» leída en el Sexto Congreso Internacional Siglo de Oro, celebrado en la Universidad Nacional de Santa Fe, Argentina, los días 29, 30 de noviembre y $1^{\circ}$ de diciembre de 2006.

${ }^{2}$ Comencé a desarrollar estas ideas en Macciuci, 2006. 
moron vanguardia más tradición registrado en países preindustriales como España y Latinoamérica. La dualidad responde, según el filósofo catalán, a que en la mayor parte de los países periféricos no se llevaron a cabo auténticas rupturas artísticas. Al no verificarse en ellos un desarrollo industrial y tecnológico avanzado tampoco experimentaron una auténtica crisis civilizatoria capaz de provocar «el gran salto revolucionario hacia delante» de determinadas vanguardias europeas (como el expresionismo alemán o el neoplasticismo ruso); por el contrario, los ismos se impusieron en los márgenes más bien «bajo el aspecto positivo de un dogma acabado que en el sentido reformador de una crítica radical de la cultura y el poder» (1989:47). En este contexto, la tradición jugó un papel fecundante, porque allí donde se mantuvieron activas las culturas históricas y artísticas primitivas ligadas a entidades nacionales y geográficas particulares, la vanguardia sorteó el peligro de la reproducción sumisa de las matrices europeas gracias al encuentro vivificante con los orígenes.

Desde diversos ángulos, otros estudios han continuado analizando tanto las razones histórico-culturales como los frutos del diálogo que vanguardia y tradición entablaron en los países alejados de los centros hegemónicos. La paradoja de lo nuevo que no renuncia al pasado es constitutiva de los movimientos vanguardistas surgidos en enclaves con escaso desarrollo tecnológico, como Latinoamérica y España, que compartieron a principios del novecientos no pocas circunstancias sociales y políticas de regiones periféricas a pesar de distanciarse radicalmente en todo lo referido a la experiencia colonial. Las contradicciones de estas atípicas y rezagadas modernidades, lejos de constituir una rémora llegaron a ser humus nutricio en la búsqueda de un arte nuevo pero enraizado en su identidad cultural. Estas razones llevan a Alfredo Bosi a recomendar al historiador de las vanguardias iberoamericanas a que en lugar de asombrarse por las paradojas se acostumbre a

\begin{abstract}
un lenguaje resbaladizo de conjunciones copulativas que suman frases semánticamente disparatadas, aunque sintácticamente mezclables: 'el modernismo fue cosmopolita y nacionalista'; 'Las vanguardias buscaron inspiración en los ismos parisienses tanto como en los mitos indígenas y en los ritos afroantillanos». O también, 'el arte latinoamericano del 20 fue no sólo absolutamente puro, sino también radicalmente comprometido'... (Bosi, 1991: 14-15, énfasis del autor).
\end{abstract}

La expresión «a la tradición desde las vanguardias» (1990:110) que Soria Olmedo propone para entender en toda su complejidad el llamado en España «arte nuevo» va en la misma dirección que Bosi. El enunciado encierra más que una simple diferencia de matices con aquellas visiones que muestran unas vanguardias escindidas, con algo de inconclusas y algo de integradas debido a una anómala pervivencia de la tradición. Se trata justamente de lo contrario: en la mirada hacia el pasado se fusiona el deseo de cimentar la propia cultura y la aspiración a integrar lo local en lo 
universal después de haber descubierto al otro lejano gracias al marco cosmopolita y totalizador de las vanguardias.

Cabe señalar además, como ilustran el propio Soria Olmedo (1990) y Luis García Montero (1998: XL ss.), que la lengua poética dominante en España en los años veinte distaba mucho de apreciar la poesía que hoy se tiene por canónica. Predominaba entonces un academicismo conservador que exaltaba composiciones de fuerte impronta casticista y de fácil elaboración ${ }^{3}$. Los versos de Gil Vicente, del cancionero, de la lírica tradicional, de Góngora más tarde, introducidos por la «gente nueva» abrieron camino hacia un acerbo olvidado que, asimilado por la estética en auge, pronto se convirtió en una lengua poética revitalizada y exigente. El impulso revalorizador de la tradición que alentaba en la construcción de una nueva discursividad estética e ideológica fue uno de los pilares del proyecto cultural más ambicioso y coherente de la España de principios del novecientos, en este caso, llevado adelante por una burguesía desigual dispuesta a madurar como clase y a modernizarse definitivamente.

...la práctica de Alberti forma parte de un bloque intelectual de la burguesía, en proceso de gestación que pretende hallar nuevos medios de expresión, más acordes en el terreno cultural con la hegemonía que está adquiriendo en el terreno político y que culminará con la toma del poder al instaurar la Segunda República... (Soria Olmedo, 1990: 112).

También sostiene el catedrático de la Universidad de Granada que dicha práctica no se puede disociar el rescate de la tradición realizada por Menéndez Pidal ni de su eficaz influencia en la generación del 27. Los poetas de la Residencia de Estudiantes (o los «asiduos visitantes», como Alberti) mantuvieron un activo intercambio con los maestros y estudiosos del Centro de Estudios Históricos, muy especialmente con Menéndez Pidal, lo que favoreció el conocimiento y la recreación de la lírica tradicio-

${ }^{3}$ Cuando en 1924 Alberti gana el Premio Nacional de Poesía con Marinero en Tierra, no fue por unanimidad. Parte del jurado se inclinaba por Julián Sánchez Prieto, quien escribía una poesía impregnada de tópicos casticistas y patrióticos:

\section{Generosa tierra mía, la que se viste de flores para recibir al hijo que vuelve de la campaña, la de los rojos claveles y los frutos como el oro ¡La que tiene los colores de la bandera de España!}

(Citado por Soria Olmedo, 1990: 111).

El dictamen deja entrever la reticencia de algunos jueces, ya que a pesar de conceder el premio, recomiendan al poeta «que sin tardar vuelva a sus lares patrios y a los penates clásicos». (Id., id.).

${ }^{4}$ A la hora de cerrar el presente artículo llegó a mis manos la recién aparecida antología de la generación del 27 publicada por Soria Olmedo en la cual amplía y actualiza sus rigurosos estudios sobre las vanguardias españolas en el marco de los procesos de modernización (Soria Olmedo: 2007). 
nal así como la incorporación de una metodología de investigación rigurosa. Las enseñanzas pidalianas alcanzarían un resultado paradigmático en los trabajos de Dámaso Alonso sobre Góngora, Gil Vicente, el romancero y la poesía tradicional ${ }^{5}$.

Similar relación entre ciencia y nuevos lenguajes poéticos, entre proyectos estéticos y político-culturales, registra Bosi en las vanguardias de Latinoamérica, donde las investigaciones lingüísticas y antropológicas, que trataban de ponerse a la par de las escuelas más prestigiosas de Francia y Alemania, se desarrollaron sincronizadamente con la creación artística. Así sucedió en Cuba, donde los estudios afroantillanos de Fernando Ortiz nutrieron la poesía de Nicolás Guillén y despertaron el interés por las raíces afroamericanas en Alejo Carpentier. Del mismo modo, los estudios del pasado incaico y preincaico de los peruanos Julio Tello y Castro Pozo fueron venero de José María Arguedas, José Carlos Mariátegui y José Sabogal (Bosi, 1991).

Román Gubern (2005: 274) analiza la presencia del mismo fenómeno de confluencia de lo nuevo y lo ancestral en la atracción que García Lorca, Alberti o Giménez Caballero sentían por el fondo flamenco, al que se sumaría más tarde la fascinación por el jazz y la negritud.

[la] dialéctica cultural entre el polo del casticismo y el del internacionalismo fue equivalente o parecida a la que generó el crisol neopopularista que se halla en García Lorca, Alberti o Giménez Caballero, que no renunciaron a la tradición popular en el marco de su modernización y experimentación estética.

Sin duda el rescate de la tradición fue una de las vías que la vanguardia exploró para encontrar un lenguaje apto para transmitir el espíritu de cambio del temprano novecientos. Los modos en que la herencia literaria se reformuló en un nuevo código estético cuentan con precisos estudios, centrados preferentemente en la reconfiguración del legado de la poesía tradicional y popular; sin embargo, son menos habituales las indagaciones dedicadas a las operaciones sobre la tradición culta realizadas en la etapa neogongorina de la vanguardia. Es más, a menudo estas se consideran manifestaciones poéticas desconectadas de las precedentes. En el presente

\footnotetext{
${ }^{5}$ El acercamiento de las letras y las ciencias en el temprano novecientos ha sido también analizado por José Carlos Mainer en sus imprescindibles estudios sobre la «Edad de Plata»: «...pero quizá lo más específico del vanguardismo español es el esfuerzo por injertar la tradición artística nacional y lo moderno. Por eso tiene honores de fasto mayor en 1927 la celebración del centenario de Góngora y a ella concurre los estudios filológicos de Dámaso Alonso y las bromas de Gerardo Diego, las emulaciones de Rafael Alberti en Cal y canto y las notas para arpa y voz de Manuel de Falla en el Soneto a Córdoba (...) Muchas veces se ha comentado que Rafael Alberti dedicó los duros de su Premio Nacional de Literatura de 1924 a comprar helados y, sobre todo, a adquirir las obras de Gil Vicente y el cancionero de Francisco Asenjo Barbieri (...) No era el único en apreciar la gracia inmarcesible de un pasado que la sencillez del presente volvía moderno» (Mainer, 190: 78).
} 
trabajo se intenta demostrar la pertinencia de proyectar al período culturalista de Rafael Alberti las tesis reseñadas hasta aquí; al mismo tiempo se busca superar el plano de la abstracción y la especulación teóricas mediante el análisis de uno de los poemas más conocidos de Cal y canto.

\subsection{Muy siglo «veinte»y muy antiguo y muy moderno}

Madrigal al billete de tranvía ${ }^{6}$

$\begin{array}{lc}\quad \text { Adonde el viento, impávido, subleva } & \text { A } \\ \text { torres de luz contra la sangre mía, } & \text { B } \\ \quad \text { tú, billete, flor nueva, } & \text { a } \\ \text { cortada en los balcones del tranvía. } & \text { B } \\ & \\ & \text { Cuyes, directa, rectamente liso, } \\ \text { en tu pétalo un nombre y un encuentro } & \text { D } \\ \quad \text { latentes, a ese centro } & \text { d } \\ \text { cerrado y por cortar del compromiso. } & \text { C } \\ \quad \text { Y no arde en ti la rosa, ni en ti priva } & \text { E } \\ \text { el finado clavel, sí la violeta } & \text { F } \\ \quad \text { contemporánea, viva, } & \text { e } \\ \text { del libro que viaja en la chaqueta. } & \text { F }\end{array}$

Cal y canto (1926-1927)

«Madrigal...» pertenece a Cal y canto, el más gongorino de los libros de poesías de Rafael Alberti, escrito entre 1926-1927 y publicado en Madrid en 1929 por Revista de Occidente. El poemario se divide en siete secciones, la quinta se compone de tres madrigales de similares características formales, de los cuales el dedicado al billete de tranvía ocupa el primer lugar; los dos restantes se titulan «Atentado»y «Tren amor».

El término «madrigal» contenido en el título encierra varias claves que orientan la lectura. En primer lugar, exhibe un cambio respecto del lenguaje poético de las anteriores secciones del libro deudoras de la dificultad y la pureza del poeta cordobés, en especial, se diferencia del apartado precedente, «4. Soledad Tercera», cuyo encabezamiento reza «Homenaje a Don Luis de Góngora y Argote (1627-1627)».

El retorno a la literatura renacentista parece anunciar un quiebre en el distanciamiento del arte deshumanizado y de la desubjetivización de la poesía de vanguardia, pues, debe recordarse, el madrigal se define como un poema estrófico cuya forma más canónica en castellano remite a un contenido

${ }^{6}$ Sigo la edición de García Montero, 1988: 347. 
de tipo amoroso expresado en estilo sencillo, de tradición rústica. Se identifica asimismo con una construcción dialógica en la cual el sujeto lírico se dirige a un receptor interno (Baehr, 1973: 402-407). El esquema que se impuso en España fue la combinación libre de endecasílabos y heptasílabos, y aunque derivó hacia temáticas muy variadas, el paradigma continúa fijado por el famoso madrigal de Gutierre de Cetina que comienza «Ojos claros, serenos, / si de un dulce mirar sois alabados, / ¿por qué, si me miráis, miráis airados?»(Ruiz Casanova, 1998:216).

Al definirse como una composición que desarrolla un tema de carácter amatorio abordado de forma sencilla y delicada, cuyos ejemplos modélicos suponen un destinatario interno femenino, el poema anticipa la presencia de un sujeto lírico y de una atmósfera de intimidad y recogimiento opuestos al gusto por la despersonalización y la extraversión de las vanguardias (además de sugerir, desde sus raíces medievales, una relación con la música muy del gusto de la poesía moderna a partir del simbolismo). Las vanguardias recogieron el legado y le dieron una impronta novecentista sin abandonar sus tópicos básicos. Guillermo de Torre, García Lorca, Dámaso Alonso, entre otros, cultivaron el madrigal en los años veinte; el propio Alberti incluye dos madrigales en Marinero en tierra («Madrigal dramático de Ardiente-y-fría» y «Madrigal de Blanca-nieve») y uno en Sobre los ángeles («Madrigal sin remedio»), por citar sólo poemarios cercanos en el tiempo a Cal y canto. Sin embargo, en «Madrigal al billete de tranvía» el poeta del Puerto de Santa María se aleja más sustantivamente del legado clásico, no sólo porque elabora un poema cuyo rasgo dominante es la dificultad y la metáfora hermética y casi conceptista sino porque exalta un objeto cotidiano en lugar del tradicional receptor interno femenino.

Desde el encabezamiento se anuncia una diversidad de registros y un libre trasiego en la tradición propios de un movimiento rupturista que entre sus méritos más reconocidos, según el señero estudio de Peter Bürger (1974), figura el de haber tomado conciencia del papel de la institución en el devenir del arte y, en consecuencia, el de haber alcanzado la plena lucidez sobre los alcances y posibilidades del medio artístico. Esta fundamental constatación significó la posibilidad de disponer y reflexionar sobre el propio medio sin sujeción a un determinado estilo o canon, abriendo las puertas a un hecho inédito en la historia del arte: que un movimiento, la vanguardia, no desarrollara ningún estilo, sino que convirtiera en un patrón estético la libre disponibilidad de todos los medios artísticos del pasado. Desde el momento en que la vanguardia transformó «la sucesión histórica de procedimientos y estilos en una simultaneidad de lo radicalmente diverso» (Bürger, 1974: 123) los artistas pudieron percibir el medio artístico en su totalidad. Este importante acontecimiento - la ruptura con la concepción lineal del arte entendido como cadena de movimientos en constante superación- no sólo derivó en un rechazo de las estéticas 
precedentes en su conjunto, sino que favoreció una operación de signo opuesto: que los artistas bebieran en la tradición y reelaboraran libremente distintos materiales del pasado en alianza con los más contemporáneos y audaces procedimientos.

Si se tiene en cuenta la novedad estética mencionada, se puede advertir que Alberti realiza una operación típicamente vanguardista al fusionar el poema estrófico renacentista de lenguaje sencillo y clásico introducido por Gutierre de Cetina, con la celebración de un objeto cifrado que remite a la imaginería urbana y moderna predilecta de la vanguardia. «Madrigal», concepto evocador del exquisito mundo renacentista italiano, queda asociado a «billete» y a «tranvía», un icono de la ciudad moderna. Desde el punto de vista formal, el autor elige una estructura uniforme y a la vez innovadora, mediante la combinación de dos serventesios y un cuarteto central; las tres estrofas, no obstante su regularidad, presentan la anomalía de un tercer verso heptasílabo ${ }^{7}$.

Por último, el género madrigal instala la expectativa de hallar un yo lírico que no se corresponde con el borramiento del sujeto de la poesía moderna según observara Ortega y Gasset en Mallarmé y retomara más tarde Mignolo en su muy citado estudio:

¿Qué puede hacer entre estas fisonomías el pobre rostro del hombre que oficia de poeta? Solo una cosa: desaparecer, volatilizarse y quedar convertido en una pura voz anónima que sostiene en el aire las palabras, verdaderas protagonistas de la empresa lírica. Esa pura voz anónima, mero substrato acústico del verso, es la voz del poeta, que sabe aislarse de su hombre circundante. (Ortega y Gasset, Deshumanización del arte, cita y énfasis de Mignolo, 1984: 65).

Recapitulando lo dicho sobre los indicios de una nueva poética contenidos en el título, se observa que si bien en Cal y canto el repliegue del sujeto alcanza cotas muy altas (como en los sonetos de la parte primera), el hecho de que el madrigal suponga un tú a quien va dirigido, atenúa de entrada esta fuerte desubjetivización. Simultáneamente surge la contravención, porque el objeto (amoroso) al que está dedicada la composición de Alberti subvierte la preceptiva: según se desarrollará en las siguientes páginas, el autor entroniza, en el lugar de la dama heredera del amor cortés a un objeto en apariencia intrascendente (cualidad cara al arte nuevo), pero de una rigurosa contemporaneidad. Como se ha podido apreciar, en las cinco palabras del título, antes de entrar en el cuerpo del poema, queda explícito el gesto libérrimo del poeta ante la tradición reformulada en vanguardia.

\footnotetext{
7 Agradezco esta y otras oportunas observaciones a Arcadio López Casanova, agudo y generoso lector de penúltimas versiones del presente trabajo.
} 


\section{El poema O EL LENGUAJE DE LAS FLORES}

Los dos endecasílabos iniciales, «Adonde el viento, impávido, subleva/ torres de luz contra la sangre mía», muestran una clara factura gongorina manifiesta en el orden sintáctico y la búsqueda de efectos plásticos y sensoriales. La referencia al viento se incrementa en el plano del significante con la aliteración de la consonante bilabial fricativa sonora /b/. La frecuencia de la grafía v (corta) recupera en la memoria culta el antiguo - e incierto- sonido de la uve, predisponiendo al lector ilustrado a pronunciarla como labiodental: «viento, impávido, subleva».

Las reminiscencias del autor de Soledades se acentúan gracias a la concentración de otros procedimientos: el adjetivo proparoxítono de clara estirpe culta, «impávido», situado en el centro del endecasílabo, o el encabalgamiento que introduce el segundo verso, remitiendo a la intermitencia de las ráfagas del viento: «subleva/torres de luz». Es herencia gongorina también la compleja sintaxis de la primera estrofa, que debe considerarse unimembre salvo si se acepta que el inexistente verbo se encuentra, tras un punto, en el «huyes» anfibológico de la siguiente estrofa. Este verbo puede referirse, anómalamente, a «billete» o a un sujeto tácito 'tú' resultado del desdoblamiento de la primera persona del poeta que, como es frecuente en el lenguaje poético, se habla a sí mismo.

La colocación estratégica de «impávido», que reúne el acento de intensidad, la sonoridad del esdrújulo y el acento rítmico central, contrapesando dos términos de similar textura fónica - aunque no gramatical ni acentual-, «viénto»y «subléva», refuerzan el efecto del adjetivo que interrumpe la cadencia como lo haría una ráfaga de viento, para luego recobrar la serenidad rítmica en el armonioso endecasílabo bimembre «torres de luz contra la sangre mía», equilibrado por la preposición «contra».

«Subleva/torres de luz» completa la huella gongorina con una imagen diáfana y relumbrante pero fundida en una figura vanguardista de intenso efecto visual, resultado de unir movimiento, humanización de objetos inertes y vértigo. Además, la asociación de «torres» y «luz» provoca la extrañeza oximorónica de una construcción atributiva de calidad intangible asociada a la recia materialidad semántica y fónica de «torres».

La segunda parte del endecasílabo, «contra la sangre mía», justifica la irracionalidad de la imagen evocando la sensación sinestésica (la luz percibida a través de la sangre, metonimia del cuerpo) de un sujeto sometido a la velocidad del tranvía en la zona abierta del vehículo, aludida mediante la metáfora «balcones», espacio que por otra parte, se llamaba también 'jardinera'. En la forma enfática, «sangre mía», se explicita la breve pero intensa presencia del yo lírico que subyace en el género madrigal y en el vocativo «tú». Así se da entrada a la isotopía semántica construida alrede- 
dor de 'jardín’ y más que 'jardín', 'jardín urbano’ que articula el madrigal: «balcones», «flor», «cortar», «pétalo, «rosa», «clavel», «violeta». La cadena metafórica se inaugura en el primer heptasílabo con un vocativo colocado de manera muy destacada, «tú, billete, flor nueva», ya que es el único heptasílabo sin anacrusis: El «billete», término real del imaginario «flor nueva» revela el objeto que motiva el madrigal bajo el pronombre «tú» invocado, con la salvedad —otra transgresión al género-, de que es un destinatario masculino e inanimado. La centralidad del sintagma «tú, billete, flor nueva», adquiere mayor relevancia aún porque encierra uno de los enigmas de sentido ${ }^{8}$.

En la estrofa central, rescatando el código del madrigal, el sujeto lírico, como se ha anticipado, mediante el verbo «huyes» puede dirigirse en segunda persona bien a sí mismo, bien a un receptor interno. Si se acepta esta segunda lectura, el poeta, en lugar de cantar la belleza de una dama, describiría, mediante una serie asindética, la contextura geométrica y plana de la nueva flor urbana, identificable con el billete, el cual, por otra parte, se suministraba mediante un aparato del que asomaban tiras de papel de distintos colores. El verso refuerza con los vocablos nucleares del endecasílabo, «directa» y «rectamente» la dureza de las consonantes oclusivas sordas del grupo $/ \mathrm{kt} / \mathrm{de}$ los dos cultismos casi homónimos. Se suma además el efecto onomatopéyico, que roza, sin serlo, lo cacofónico, y proporciona un tópico maquinista, posible referencia al dispositivo de venta y corte del billete. El conjunto configura una imagen propia de la primera vanguardia en la que asoman los orígenes ultraístas de la poesía albertiana.

En el núcleo de la estrofa central, el verso sexto deja ver el secreto de la fascinación oculta del billete de tranvía: «En tu pétalo un nombre y un encuentro/latentes». El pequeño objeto parece encerrar una promesa abierta al encuentro con el otro y si se considera que desarrolla la imagen base precedente, («billete, flor nueva»), es pertinente interpretarla como una continuación de la misma metáfora cuya relevancia se destaca por un acento extrarrítmico. «Pétalo» y «latentes» funcionan, con sus sonidos oclusivos, duros, /p/ y /t/, como coraza protectora o estuche, de «nombre» y «encuentro», voces pertenecientes a un campo semántico opuesto a la isotopía de la máquina presente en el primer endecasílabo de la estrofa.

\footnotetext{
${ }^{8}$ La asociación metafórica de los objetos urbanos con una serie de referencias gratas y familiares en torno al campo semántico de 'jardín' logra contrarrestar el shock agresivo de la metrópolis sobre el sujeto sometido a sus estímulos. José del Pino (1995) ha analizado un procedimiento similar en Cazador en el Alba, una de las novelas vanguardistas de Francisco Ayala. En las descripciones urbanas, el narrador recurre a metáforas relacionadas con el mundo rural para dar a entender que el protagonista evita la enajenación ante lo desconocido mediante la explicación de lo nuevo a partir de la los saberes de su anterior vida campesina: «Grandes rebaños de maletas se orientaban hacia prados recién florecidos de ventiladores (Ayala: 1989: 89).
} 
Después del esdrújulo «pétalo» el endecasílabo se distiende en uno de los más largos del madrigal (el que más sinalefas acumula, la última compuesta por un triptongo). De este modo el poema se desliza por una cadencia prolongada, sólo rota por el encabalgamiento que traslada al verso siguiente el adjetivo, «latentes», índice de la espera y del desasosiego de la cita y, al mismo tiempo, del movimiento desacompasado del tranvía, que se continúa en el sintagma «a ese centro/ cerrado y por cortar del compromiso». Aquí el verbo central, «cortar», refuerza fonéticamente el significado denotado con las oclusivas sordas y las vibrantes. La centralidad de este momento del madrigal queda destacada al mismo tiempo por la estructura estrófica de cuarteto y por las vocales de las rimas (î/o-é/o-é/o-í) diversas de las utilizadas en los serventesios (/ é/a-í/a-é/a-ía) y (î/a-é/a-í/aé/a). La diferenciación de esta estrofa sustenta una estructura enmarcada del poema, que se contrapone al esquema secuencial de las tres unidades. De este modo, la centralidad del cuarteto es reforzada por el tipo de estrofa y por la rima, conjugándose todos los elementos para realzar el momento de más intensidad y más enigmático del poema. El sustantivo «centro», asociado en el campo léxico y en el plano fónico a «encuentro», «cerrado» acentúan la función nodal de esta estrofa.

La última parte del poema permite interpretar en clave metapoética el encuentro y el objeto que preanuncia el billete. Una serie de símbolos de larga tradición literaria descubren tras las imágenes cotidianas una reflexión estética y un manifiesto artístico. El billete, esa nueva flor urbana, no guarda («no arde en ti») la prestancia de la rosa, ni la gracia del clavel, que está muerto, «finado»; en cambio, encierra la discreción silenciosa de la violeta «viva, contemporánea, del libro que viaja en la chaqueta». Como suele ocurrir en los sonetos clásicos, la clave está cifrada en los últimos versos. El billete, rectilíneo, rectangular y a la vez, flor nueva, puede considerarse un término figurado para referirse al libro, ese «que viaja en la chaqueta», aún cerrado; en cuya tapa (pétalo) se anuncia el título (un nombre), es decir, la lectura (un encuentro latente). Sin embargo, la anfibología entre billete real y metafórico no se deshace totalmente, pues ambos pueden coexistir en el tranvía. Tampoco se aclara la ambigüedad gramatical del pronombre «ti», que puede referirse, igual que «huyes», al objeto del madrigal, el libro/billete, o indicar el desdoblamiento autorreferencial de la segunda persona. Entonces, el sujeto lírico sentiría arder («arde en ti»), el deseo de entregarse a la lectura silenciosa del libro que lleva en su bolsillo.

Las flores no han sido elegidas al azar, un análisis de su simbolismo autorizan a leer el madrigal como propuesta poética. En el lenguaje gongorino de la vanguardia han irrumpido los objetos de la modernidad, ya no está vigente el espacio preciosista que inspiraba a la excelsa musa de Juan Ramón, quien en 1919 había comenzado su Piedra y cielo con el 
famoso «Poema. 1»: «¡No le toques ya más, / que así es la rosa!» (Gaos, 1979: 28). Tampoco sirve el clavel, cuyo lugar simbólico en España es ostensible y en el contexto de «Madrigal...» queda asociado a la poesía con fondo telúrico, como la albertiana anterior a 1926 que el autor consideraba agotada. Cabe recordar el propósito que animaba Cal y Canto según quedó consignado más tarde en La arboleda perdida: abandonar «el poema breve, rítmico, de corte musical», es decir, el que caracterizaba la etapa neopopularista precedente, pues ya le producía al poeta del Puerto de Santa María el hastío de «un limón exprimido del todo, difícil de sacarle un jugo diferente». En su lugar, se propuso someter «el verso métrico a las presiones —y precisiones — más altas» (Alberti, 1988: 234).

La flor-poesía, «la violeta (...) del libro» se dispersa en la nueva ambigüedad gramatical de este sintagma, que puede indicar tanto identidad (similar al enunciado «el clavel de sus labios»), como contigüidad (la típica violeta disecada y guardada en un libro), o pertenencia (la violeta es propiedad del libro). De cualquier modo, se trata de una flor de signo opuesto al vistoso clavel y a la aristocrática rosa. De forma inadvertida, se instala en el discontinuo espacio de la urbe y se confunde con el billete y con el libro pequeño, ambos artificiales, mecánicos, pequeños, humildes; también discretos y utilitarios. Mantiene los atributos de la violeta, oculta, recatada, pero — se aplica en subrayarlo el sujeto lírico- es además contemporánea y está viva; todo lo contrario de la fúnebre flor de los clásicos y la mitología, símbolo de muerte y del umbral al más allá: no la «vïola troncada ${ }^{9}$ de uno de los más famosos sonetos de Góngora ni las premonitorias «negras víolas» ${ }^{10}$ del tálamo de Acis y Galatea del igualmente

${ }^{9}$ La viola troncada representa el paso último entre la declinación de la vida y la degradación después de la muerte, descriptas en el soneto de Góngora (1967, II: 135):

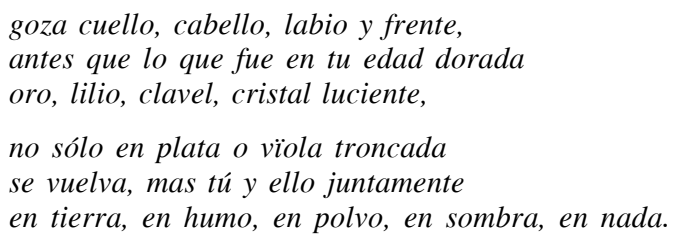

${ }^{10}$ La octava XLII de La fábula de Polifemo y Galatea preanuncia la unión de Acis y Galatea con la descripción del lecho, en el que llueven negras violetas, anticipo de la adversidad (muerte de Acis) y blancos alhelíes, que simbolizan la permanecia de la belleza (metamorfosis del mancebo):

No a las palomas concedió Cupido Juntar de sus dos picos los rubies

Cuando al clavel el joven atrevido Las dos hojas le chupa carmesíes. Cuantas produce Pafo, engendra Gnido, 
célebre Polifemo del poeta cordobés. Muy distante igualmente de las fúnebres violetas de Hamlet $^{11}$ y de la morbidez decadentista, más cercana en el tiempo, de «Viola Acherontia», cuento de Leopoldo Lugones ${ }^{12}$. La flor de Alberti es nueva y vital; el poeta completa la metamorfosis con la recuperación para la lírica de la voz patrimonial, 'violeta', en lugar del elegante y sin duda más eufónico cultismo clásico.

Violeta viva, aunque aplastada y fusionada con el libro que viaja en la chaqueta por lo tanto, de formato reducido, un libro que cabe en el bolsillo. Es relevante para el sentido del poema tener presente que el clásico emblema de la cultura letrada había empezado a acompañar a la modernidad de principios del entresiglos XIX y XX con cambios de formato, clara señal de la adaptación de la industria editorial a los nuevos espacios y a la aparición de otra clase de público lector. Alberti parece prefigurar el primer libro de bolsillo en castellano, lanzado por Austral en Argentina en $1937^{13}$.

Produce extrañeza que la flor que elige el poeta para identificar su quehacer poético es el símbolo de la modestia, en abierta contradicción con el lenguaje suntuario y gongorino de Cal y canto. Pero no es anómalo si se recuerda la admiración que el poeta gaditano manifestó por la poesía de Bécquer, reconcentrada e íntima. Sería muy extenso mencionar las citas y reconocimientos al autor de Rimas que Alberti despliega en su obra, baste recordar el título de los tres libros de Sobre lo ángeles y el motivo de la violeta asociada al siglo XIX en «Invitación al arpa» ${ }^{14}$. Importa observar

\section{Negras víolas, blancos alhelies, \\ Llueven sobre el que Amor quiere que sea \\ Tálamo de Acis y de Galatea.}

(Alonso, 1967, III: 27)

11 También Shakespeare (1900: 99 y 114) asocia las violetas a la muerte en dos momentos de Hamlet: en el acto IV, con la imagen de estas flores marchitas, Ofelia recuerda al príncipe de Dinamarca el asesinato de su padre: «I would give you some violets, but they withered all when my father died». Más adelante, en el acto V, Laertes se consuela con las violetas que brotarán de los bellos miembros de su hermana ahogada, tras resignarse al entierro profano de la joven bajo sospecha de suicidio: «Lay her i' the earth; And from her fair and umpolluted flesh May violets spring!».

12 Leopoldo Lugones, Las fuerzas extrañas, 1906.

13 El consorcio de poema, lectura y transporte urbano lleva a recordar «Veinte poemas para ser leídos en el tranvía» de Oliverio Girondo, publicados en 1922. Aunque la amistad de los dos poetas se inicia años más tarde, durante el exilio de Alberti, sin duda el poemario de Girondo fue conocido tempranamente por el autor de Marinero en tierra, pues Gómez de la Serna, entre otros críticos, le dedicó una elogiosa reseña en El Sol el mismo año de publicación. Seguidamente, en 1923, Girondo viaja por la península y en 1925 publica en España Calcomanías. Son por otra parte numerosos y bien conocidos los testimonios del intenso intercambio entre los vanguardistas españoles y latinoamericanas, y en particular, entre el autor de En la masmédula y el creador de las Greguerías (Bonet, 1995: 293-294).

14 «Si las violetas se aburren / es porque están nostálgicas de moaré y abanicos» («Invitación al arpa», Sobre los ángeles, 1989: 144). En este poemario Alberti también retomará 
que aún en su poesía más pura y culturalista, no abandona totalmente sus referentes más preciados ni deja de observar y poetizar la realidad cotidiana. Cal y canto constituye un inventario del mundo moderno, no una huida al refugio del Olimpo. Los dioses de Alberti son terrenales, y también los ángeles, como se verá unos años más tarde en el poemario surrealista de 1929.

Los datos del libro/billete guardan para el viajero la clave de la cita, «un nombre y un encuentro», pero al mismo tiempo el billete puede entenderse como un objeto que se guardará, que llevará a cabo el «encuentro» metafórico en/con el libro, feminizado a través de la violeta. Este último sentido del poema ilumina esa huida hacia «el centro por cortar del compromiso», tanto si se trata del viajero ansioso por entregarse a la lectura, como del billete que se desliza entre las hojas «sin cortar»: la imagen puede interpretarse como una alusión a las páginas de los libros antiguos, llamados 'intonsos' porque eran encuadernados sin cercenar los bordes de los pliegos. En consecuencia, es lícito interpretar que el paseante está deseoso de continuar una lectura ya iniciada y luego interrumpida, pues en la primera estrofa se indica que la flor nueva ha sido «cortada», alusión nuevamente anfibológica, aceptable tanto para el billete como para las páginas, ya leídas, del libro. El billete y el libro se funden en un significado común, real y simbólico: la invitación al viaje, a la aventura y a lo desconocido.

El ritmo acelerado de la primera estrofa parece decrecer, al comienzo del endecasílabo de la última estrofa, frente al retorno del tono afable y obsequioso del madrigal junto con el verso armonioso, dilatado por las sinalefas ( $\mathrm{Y}$ no arde en ti la rosa»). Pero inmediatamente sucede un gran dinamismo acentual, con acentos extrarrítmicos («finado») y antirrítmicos, en contacto, muy violentos («en tí príva» y «clavél, sí») que provocan una distorsión brusca, entrecortada, como lo es la sucesión de sonidos fricativos y oclusivos, sordos y sonoros, de las consonantes. Los dos violentos encabalgamientos sucesivos, «priva/ el finado» y «violeta/ contemporánea» dan todavía mayor agitación y movimiento a la estrofa, que repentinamente se frena con el bisílabo «viva».

El segundo hipérbaton aumenta su efecto desestructurante por la naturaleza del adjetivo, escasamente poético, «contemporánea», que irrumpe en el encabalgamiento como si de un collage cubista se tratara: el vocablo de seis sílabas, con predominio de consonantes sordas implosivas con final en

el motivo de la rosa con una similar función metapoética, cuestión que no es posible desarrollar aquí. Las tres secciones del libro se titulan de la misma manera, «Huésped de las nieblas», cita de la rima LXXV de Bécquer. Soria Olmedo ha recogido la sentencia del propio Alberti: «Mis abuelos, italianos. Mis abuelas, andaluzas. Pero yo soy noruego, por intuición y por simpatía personal a Gustavo Adolfo Bécquer» (Soria Olmedo, 1990: 15). 
hiato desafina en la brevedad del heptasílabo como los objetos cotidianos, no artísticos, sobresalen en la tela del pintor ${ }^{15}$. Tanto el plano fónico, con la alternancia de sonidos fricativos y líquidos, «viva», «libro», «viaja», interrumpidos por los fonemas oclusivos y africados de «contemporánea», «que»y «chaqueta», como el ritmo alterado de los versos centrales del serventesio actualizan ante el lector el ámbito del madrigal, que ya no es una corte renacentista sino un tranvía, cuyo movimiento discontinuo evoca, reforzado por la reiteración - reaparece el efecto cacofónico del quinto verso-, del difícilmente poético, en castellano, grupo $/ \mathrm{Kt} /$, interrumpido por el quizás menos eufónico aún sonido africado de la ch, que «chirría» en cualquier verso. La particular discordancia de este endecasílabo se destaca no sólo porque cierra el poema sino porque rompe en el plano fónico el paralelismo de los tres finales de estrofa, todos endecasílabos con acentos en sílabas pares en $2^{\mathrm{a}}, 6^{\mathrm{a}}$ y $10^{\mathrm{a}}$ sílabas y un especial ritmo regular y moroso.

Por último, continuando con el desciframiento de significaciones convergentes, se puede develar un nuevo sentido en el motivo del billete, que lleva una promesa escrita. 'Billete' significa también carta breve, esquela que en los cotillones y las fiestas galantes se utilizaba para invitar a la dama elegida. El mensaje breve de amor toma un nuevo rostro, una forma y funcionalidad diferentes en el espacio urbano, el nuevo ámbito del poeta donde 'billete' evoca las dimensiones reducidas que ha adquirido el libro. Pero el canto a lo pequeño guarda también otra clave metapoética, pues según observa Leo Geist en su conocido estudio sobre los poetas de vanguardia, el poema breve fue considerado en los años veinte como «una de las manifestaciones más claras de la fusión de modernidad y tradición», y un receptáculo ideal para albergar una «micropoética» y expresar los propios postulados artísticos (Geist, 1980: 150). La lectura completa del poema en clave de manifiesto da nueva luz al título, que en este contexto se puede entender como una alusión a las formas líricas breves apreciadas por los poetas de su generación.

El madrigal anunciado en el título perdura, con nuevo diseño, en el canto a dos objetos enclavados en la revolución mecánica y urbana de los albores del siglo XX. La operación vanguardista anunciada en el título a través de la yuxtaposición de lo nuevo y lo clásico ha doblado la apuesta en el cuerpo del poema, pues el registro sencillo que Gutierre de Cetina hizo célebre se vuelve en el madrigal albertiano sellado discurso neogongorino y fragmentaria representación vanguardista.

${ }^{15}$ Posiblemente en los años veinte el adjetivo 'contemporánea' no se hallaba tan impuesto como hoy entre los hablantes, por lo tanto, su introducción en el registro lírico resultaría aún más sorprendente. 


\section{CONCLUSIONES: FIESTA Y FRACASO DEL INTELECTO}

No deja de ser un signo del contradictorio rostro polimorfo de las vanguardias la búsqueda de un arte más cercano a la vida, atento a los cambios de la cultura de masas, pero envuelto en el hermético discurso de Góngora impregnado del registro moderado del arte renacentista. Alberti rescata la herencia cortesana del madrigal para enaltecer objetos pertenecientes a la cultura letrada pero también cosmopolita. El audaz consorcio clásico-barroco del poema no constituye un simple reconocimiento del legado de la tradición, es un material transformado, re-creado, con el que se construye un discurso poético revelador de una cultura que sufre transformaciones profundas.

Se trata de textos poéticos que requieren del lector una actitud y una competencia críticas renovadas. Haciendo propio el razonamiento de Leo Geist (1980: 12), los poemas de los años veinte no requieren exégetas, los rechazan; llaman a la penetración instintiva, no al desentrañamiento del concepto, porque ya los hombres y los poetas no confían en la inteligibilidad absoluta. Llegado el punto en que el intelecto fracasa, es necesario un salto de la imaginación para captar la idea intuitivamente. El tropo antisentimental, parco en la expresión de las emociones que singulariza al arte deshumanizado, se conjuga con el costado inorgánico y fragmentario de la realidad. La sugestión es más importante que el contenido; la dinámica de la imagen supera al significado y el discernimiento no es un objetivo primordial de la poesía ${ }^{16}$.

La metáfora es para ellos [los ultraístas y los del 27] más que una operación puramente intelectual; es también un proceso mágico, precisamente por su poder creativo. El poema da expresión por medio de construcciones lógicas a una esencia que resulta en último término impenetrable por vía puramente intelectiva. (...) La magia lingüística (sugestión) es más importante que el contenido lingüístico; la dinámica de la imagen supera su significado. La inteligibilidad no es el fin principal de esta poesía (Geist, 1984: 283-284).

No es fácil discernir hasta dónde concreta Alberti su propósito de alcanzar «las precisiones más altas» y hasta dónde la tensión entre intelectualismo culturalista e irracionalidad que atraviesa la poesía de vanguardia afecta a Cal y canto y subvierte el esquema gongorino. ¿Es válido interpretar que un sujeto se desdobla y se dice a sí mismo «huyes directamente» $\mathrm{y}$ «rectamente liso»?, ¿son modificadores aceptables para una acción humana? Sí, si se acepta que el sujeto confundido entre la multitud y la

${ }^{16}$ La observación de Geist puede asociarse al concepto de tensión disonante mediante el cual Hugo Fridrich explica el carácter oscuro e ilógico de la lítica moderna (1974: 21 y ss.). 
máquina puede vivenciar una suerte de cosificación; sí, si se recuerda que el surrealismo ya era conocido y cultivado en España, y que el hombre desguarnecido y vacío de «Sobre los ángeles» estaba ya gestándose. Al comienzo del madrigal «torres de luz» sublevan al viandante, que poco tiempo después, en Sobre los ángeles, será «un carbón ardiendo», «un negro saco,/ a la ventana» ${ }^{17}$; es plausible, entonces que atraviese la aglomeración del tranvía con un impulso mecánico y veloz.

Por otra parte, y desde una concepción opuesta a la sustentada por el surrealismo, el cubismo había reemplazado el punto de vista único y había impuesto en pintura la fragmentación, la simultaneidad y la superposición de los objetos, representados desde una multiplicidad de puntos de vista. La recreación intelectual e intuitiva llegó por momentos a la disolución de la imagen y a la abstracción. Una de las formas de contrarrestar el hermetismo creciente fue el collage: los objetos de la vida diaria, como un trozos de periódico, o un billete, como el que es motivo vertebrador de este madrigal, adquirirían, «pegados» en la tela, otro significado sin perder el original; a la vez introducían en el ámbito del cuadro fragmentos de vida que unían el arte elevado y la realidad cotidiana.

En el contexto de los ismos, impregnadas de las reminiscencias de sus distintos códigos estéticos y de la exploración de lo real más allá del mundo sensible, las imágenes del poema de Alberti pierden el centro, se solapan y ofrecen itinerarios diversos al lector. «Madrigal»... deja entrever, con sus ambigüedades no resueltas $-\mathrm{y}$ quizas, deliberadas- y su perspectiva calidoscópica, que la precisión y la exactitud del discurso clásico quedan vulneradas por la imposibilidad de una lectura única. A pesar de pertenecer al proyecto más gongorino del autor de Marinero en tierra, es decir, el más abocado a la exactitud y el rigor, comparte la inestabilidad y el carácter abierto de la obra inorgánica.

La admiración de los poetas del 27 por el luminoso autor de las Soledades no parece estar reñida, por tanto, con el hermetismo de nuevo cuño de las vanguardias, ni se muestran incompatibles la dificultad conceptista, la erudición y el juego de ingenio clásicos con las representaciones de mundo de principios del siglo $\mathrm{XX}^{18}$. En este sentido, es momento de apuntar que los nuevos lineamientos teóricos que sitúan las obras en el contexto de la cultura y las mentalidades han impulsado aproximaciones críticas que trascienden la tradicional visión formalista de la disciplina. Esta pers-

17 «El cuerpo deshabitado» 1, Sobre los ángeles: 73.

${ }_{18}$ No es posible en este breve espacio realizar un estudio de la mayor o menor cercanía de las metáforas de Cal y canto al concepto en sentido clásico. Sería interesante profundizar hasta qué punto Alberti se propuso seguir a Góngora y hasta dónde triunfó el espíritu moderno y rupturista, pero lo cierto es que en el siglo XX no se podía reproducir el esquema de pensamiento del XVII, como bien apunta Geist. 
pectiva favorece la integración de las producciones literarias en la red de las expresiones artísticas y simultáneamente, interpretarlas en el marco del proyecto utópico y totalizador de las vanguardias ${ }^{19}$.

Los sucesivos ismos intentaron atrapar la realidad cambiante de comienzos de la anterior centuria. Rafael Alberti fue, entre los poetas de la generación vanguardista española, quien mejor dio cuenta de las instantáneas que buscaron captar la modernidad radical del novecientos mediante un encadenamiento acelerado de paradigmas estéticos (Wilson, 1990). En Cal y canto lo intentó con la herencia culterana, conjugando pureza y heterodoxia. Tributo a las Soledades, sí; poesía guardada, como lo expresó el autor en sus memorias, en «cofre de cristal de roca», en «blanca y dura urna», también, pero surgida del vértigo del presente. La poesía neogongorina de Alberti ejercitó desde la tradición las premisas de la dificultad y el distanciamiento del arte deshumanizado, sin dejar de ser muy de vanguardia. Impregnada de las vivencias de la velocidad, lo inventos recientes y la ciudad cosmopolita, supo traducir en versos depurados la fascinación y el desasosiego del sujeto moderno ante la transformación acelerada del mundo conocido.

\section{REFERENCIAS BIBLIOGRÁFICAS}

ALBERTI, Rafael (1959): La arboleda perdida. Libros I y II de Memorias. Barcelona: Seix Barral, 1988.

-. (1929) Cal y canto (1926-1927), en Obras completas. Tomo 1. Poesía. 1920-1938). García Montero, Luis (ed., intr. y notas). Madrid: Aguilar, 1988, pp. 299-375.

—. Marinero en tierra (1924). GIMFERRER, Pere (pról.). Barcelona: Lumen, 1977.

- Sobre los ángeles - Yo era un tonto y lo que he visto me ha hecho dos tontos (1929). Brian Morris, C. Madrid: Cátedra, 4ta. ed. 1989.

Antología de Góngora. Comentada y anotada. ALONSO, Dámaso (ed.). En Góngora y el «Polifemo», t. II. Madrid: Gredos, 1967, 3 tomos.

Fábula de Polifemo y Galatea. Edición comentada y anotada. En Góngora y el «Polifemo», t. III, 1967: op. cit.

AYALA, Francisco (1929). Cazador en el alba (1928). El boxeador y un ángel. Navarro Durán, Rosa (Intr). Madrid: Alianza, 1988.

BAEHR, Rudolf. Manual de versificación española. Madrid: Gredos, 1973.

BONET, Juan Manuel. Diccionario de las vanguardias en España. 1907-1936. Madrid: Alianza, 1995.

${ }^{19}$ La revisión de los fundamentos de su propia perspectiva formalizante que realiza Leo Geist diez años después de sus primeras aproximaciones a la poesía del 27 es un claro indicio del giro teórico experimentado en los estudios de la vanguardia: «Llevo años estudiando la producción poética de la generación del 27 . Ultimamente voy llegando a la convicción de que el 27 no se entiende sin inscribirse dentro de un contexto vanguardista. Esto va a contrapelo de una tradición crítica de la que soy heredero y al mismo tiempo he contribuido (...) Me interesa el signo ideológico del texto poético, y me atrae cada vez más el texto difícil, aparentemente no-ideológico» (1999: 429). 
BOSI, Alfredo. «La parábola de las vanguardias latinoamericanas». En: SCHWARTZ, Jorge (ed.). Las vanguardias latinoamericanas. Textos programáticos y críticos. Madrid: Cátedra, 1991, pp. 13-63.

BÜRGER, Peter (1974). Teoría de la vanguardia. Barcelona: Península, 1987.

FRIEDRICH, Hugo (1974). Estructura de la lírica moderna. Barcelona: España: Seix Barral. GAOS, Vicente. Juan Ramón Jiménez. Antolojía poética. , 5ta. ed. Madrid: Cátedra, 1979.

GARCÍA MONTERO, Luis. "Prólogo". En ALBERTI, Rafael. Obras completas. Tomo I. Poesía 1920-1938, op. cit., XXXI-CXXXIV.

GEIST, Anthony Leo. Las poéticas de la generación del 27 y las revistas literarias: de la vanguardia al compromiso (1918-1936). Madrid: Guadarrama, 1980.

—. «El 27 y la vanguardia: una aproximación ideológica». Cuadernos Hispanoamericanos. La generación de 27. Abril-mayo 1993, 514-515, pp. 53-64. Reproducido en WENTZLAFF-EGGEBERT, Haral. Las vanguardias literarias en España. Bibliografía y antología crítica, Mdrid, Frankfurt: Iberoamericana-Verruert, 1999, pp. 429-441.

GIRONDO, Oliverio (1922). Veinte poemas para ser leídos en el tranvía. Calcomanías. Espantapájaros: Buenos Aires: CEAL, 1981.

GUBERN, Román. «Ruido, furia y negritud: nuevos ritmos y nuevos sones para la vanguardia». En MECHTIHILD, Albert (ed.). Vanguardia española e intermedialidad, Madrid-Frankfurt am Main: Vervuert-Ieroamericana, 2005. pp. 273-302.

LUGONES, Leopoldo (1906): «Viola acherontia». En BARCIA, Pedro Luis (estud. prel. y notas). Las fuerzas extrañas. Buenos Aires: Ediciones del 80, 1981, pp. 125-131.

MACCIUCI, Raquel. Final de plata amargo. De la vanguardia al exilio. Ramón Gómez de la Serna, Francisco Ayala y Rafael Alberti. La Plata: Al Margen, 2006.

MAINER, José-Carlos. «Cultura y vida nacional (1920-1939): la época de Alberti». Cuadernos Hispanoamericanos. Homenaje a Rafael Alberti, 486-486, nov-dic., pp. 69-80.

MIGNOLO, Walter. «La figura del poeta en la lírica de vanguardia. (V. Huidobro, O. Girondo, O. Paz)». En Textos, modelos y metáforas. México: Universidad Veracruzana, pp. $61-75,1984$.

PINO, José Manuel del. Montajes y fragmentos: Una aproximación a la narrativa española de vanguardia. Amsterdan - Atlanta: Rodopi, 1995.

RUIZ CASANOVA, José Francisco. Antología Cátedra de Poesía de las Letras Hispánicas. Madrid: Cátedra, 1998

SHAKESPEARE'S (1601). Hamlet, Prince of Denmark. (Stanley Wood, M.A. and Rev. F. Marshall, M.A. (eds). The Oxford \& Cambridge Edition. London: George Gill \& Sons Ltd., 1900.

SORIA OLMEDO, Andrés. «La depuración de la mirada. En torno al neopopularismo en Rafael Alberti». Cuadernos Hispanoamericanos. Homenaje a Rafael Alberti, 1990, 485486, op. cit., pp. 109-118.

- Las vanguardias y la Generación del 27. Madrid: Visor-Centro para la Edición de los Clásicos Españoles, 2007.

SUBIRATS, Eduardo (1986). El final de las vanguardias. Madrid: Anthropos, 1989.

TEJADA, José Luis. Rafael Alberti, entre la tradición y la vanguardia. (Poesía primera: 1920-1926). Madrid: Gredos, 1977.

WILSON, Jason. «'Más o menos surrealístico': la modernidad de Rafael Alberti». Cuadernos Hispanoamericanos, Homenaje a Rafael Alberti, nov.-dic., 1990, op. cit., pp. 59-67.

Fecha de recepción: 30 de septiembre de 2008

Fecha de aceptación: 10 de marzo de 2009 